Удк 657.6:338.45:69

\title{
Віталій Микитюк
}

\section{ОЏНЮВАННЯ ЕФЕКТИВНОСТІ ІННОВАЦЙНОЇ ДІЯЛЬНОСТІ ПІДПРИЕМСТВ ЗА ЇЇ СКЛАДОВИМИ}

Вказано, що оцінювання ефрективності інноваційної діяльності підприємства є однією з важливих фрункцій управління нею, що перебуває у складному діалектичному взаємозв'язку з іншими фрункціями та виступає передумовою подальшого зростання інноваційної активності підприємства.

Зазначено, що сфрормована сукупність кількісних показників за кожною складовою дозволяє розкрити вплив від здійснення інноваційної діяльності на підприємстві на відповідні сфрери його діяльності: виробництво, економіку, фрінанси, маркетинг, наукову та соціальну сфрери, природоохоронну діяльність.

Встановлено, що розраховані інтегральні показники за складовими ефеективності інноваційної діяльності надають можливість проаналізувати їі динаміку на підприємствах, а також визначити найефрективніші напрями здійснення інноваційної діяльності. Крім того, вони є базою для побудови діаграми ефективності інноваційної діяльності підприємства, яка служить інструментом ї̈ якісної оцінки.

Обгрунтовано методичні положення оцінювання ефрективності інноваційної діяльності підприємств, які базуються на врахуванні економічної, науково-технологічної, фрінансової, соціальної, маркетингової, ресурсної та екологічної складових з використанням інтегральних показників, розрахованих методом адитивної згортки.

Доведено необхідність використання одного з двох рекомендованих способів оцінювання ефрективності інноваційної діяльності підприємства: на основі розрахунку узагальнюючого інтегрального показника ефрективності інноваційної діяльності або з використанням пелюсткової діаграми ефективності інноваційної діяльності. Діаграма ефрективності інноваційної діяльності підприємства дозволяє виявити їі складові, що знаходяться у зоні "низької", "середньої" та "високої" ефрективності й відповідно цього розробляти заходи щодо удосконалення інноваційної діяльності на підприємстві.

Ключові слова: інноваційна діяльність, оцінювання ефрективності, інтегральний показник ефективності, складові інноваційної діяльності, динаміка показників, діаграма ефрективності.

JEL: M11, O30, E22

Постановка проблеми. Економічний стан держави й окремих секторів економіки України значною мірою визначається темпами і масштабами розвитку промисловості як пріоритетної галузі. Це зумовлює загострення уваги до фрормування організаційноекономічного механізму підвищення ефективності інноваційної діяльності у промисловості, складовою частиною якого $€$ науково обґрунтоване аналітичне забезпечення зростання ефрективності взаємопов'язаних інвестиційних та інноваційних процесів.

Вагомість аналітичних аспектів забезпечення ефективності інноваційної діяльності в промисловості актуалізується через загострення конкуренції на інвестиційному ринку та

(С) Віталій Микитюк, 2017. 
посилюється специфрікою галузі: тривалий цикл інноваційних проектів, нестача джерел фінансування, необхідність обґрунтування пріоритетів при розподілі ресурсів.

Аналіз останніх досліджень і публікацій. Розробкою проблем оцінки ефективності інноваційної діяльності та інвестицій в інновації займались такі вчені, як: В. Александрова [6], Л. Антонюк [1], Р. Бондарчук [2], О. Бородіна [3], В. Геєць [5], А. Гриньов [4], С. Ілляшенко [10], П. Микитюк [7], Н. Мешко [9], В. Пономаренко [11] та ін.

Однакдеякі теоретичні та науково-практичні проблеми, пов'язані з оцінкою ефрективності інноваційної діяльності на основі врахування її впливу на різні сфери діяльності підприємства, не отримали до теперішнього часу належної наукової розробки та узагальнення. Тому виникає об'єктивна необхідність у подальшому поглибленні теоретичних і методичних положень щодо оцінки ефективності інноваційної діяльності та розробці на цій основі комплексу заходів для ії підвищення.

Метою статті є обґрунтування та розроблення рекомендацій щодо вдосконалення оцінювання ефективності інноваційної діяльності підприємств.

Виклад основного матеріалу. На рівні окремого підприємства розроблення заходів щодо вдосконалення інноваційної діяльності має базуватися на оцінці ефективності інноваційної діяльності та аналізі можливостей їі підвищення. Було визначено ефективність інноваційної діяльності за сімома складовими (економічною, фрінансовою, науковотехнологічною, маркетинговою, соціальною, ресурсною та екологічною) для трьох промислових підприємств. Аналіз коливань отриманих значень інтегральних показників ефективності інноваційної діяльності за складовими дає змогу виділити для кожного підприємства складові, для яких характерні нестабільність та динамізм та складові, що характеризуються стійким рівнем ефективності (табл. 1).

Табличя 1

Коливання інтегральних показників ефективності інноваційної діяльності заїї складовими протягом 2012-2016 рр.

\begin{tabular}{|c|c|c|c|c|}
\hline \multirow{2}{*}{$\begin{array}{c}\text { Складові } \\
\text { ефективності } \\
\text { інноваційної } \\
\text { діяльності }\end{array}$} & \multirow[b]{2}{*}{$\begin{array}{c}\text { Параметр, що } \\
\text { аналізується }\end{array}$} & \multicolumn{3}{|c|}{ Підприємства } \\
\hline & & $\begin{array}{c}\text { ТОВ } \\
\text { “Тервікно- } \\
\text { пласт” }\end{array}$ & $\begin{array}{l}\text { TOB “Карпат- } \\
\text { нафтохім” }\end{array}$ & $\begin{array}{c}\text { TOB } \\
\text { “Кеннер- } \\
\text { Україна" }\end{array}$ \\
\hline \multirow{3}{*}{ Економічна } & Максимальне значення & 0,507 & 0,243 & 0,308 \\
\hline & Мінімальне значення & 0,091 & 0,066 & 0,144 \\
\hline & Відхилення & 0,416 & 0,177 & 0,164 \\
\hline \multirow{3}{*}{ Маркетингова } & Максимальне значення & 0,732 & 0,900 & 0,510 \\
\hline & Мінімальне значення & 0,375 & 0,598 & 0,406 \\
\hline & Відхилення & 0,357 & 0,302 & 0,104 \\
\hline \multirow{3}{*}{ Соціальна } & Максимальне значення & 0,765 & 0,828 & 0,929 \\
\hline & Мінімальне значення & 0,176 & 0,166 & 0,587 \\
\hline & Відхилення & 0,589 & 0,662 & 0,342 \\
\hline \multirow{3}{*}{ Ресурсна } & Максимальне значення & 0,885 & 0,900 & 0,986 \\
\hline & Мінімальне значення & 0,599 & 0,776 & 0,769 \\
\hline & Відхилення & 0,286 & 0,124 & 0,217 \\
\hline \multirow{3}{*}{ Екологічна } & Максимальне значення & 0,988 & 0,891 & 0,736 \\
\hline & Мінімальне значення & 0,341 & 0,618 & 0,600 \\
\hline & Відхилення & 0,647 & 0,273 & 0,136 \\
\hline
\end{tabular}

Джерело. Складено автором. 
На ТОВ “Тервікнопласт” стабільні значення ефективності спостерігалися за ресурсною, фінансовою і маркетинговою складовими. Враховуючи, що інтегральні показники ефрективності за ресурсною складовою в аналізованому періоді постійно знаходились у зоні "високої" ефективності, а інтегральні показники ефективності за фінансовою та маркетинговою складовими - здебільшого в зоні "середньої" ефеективності, можна стверджувати, що перелічені складові ефективності інноваційної діяльності підприємства не потребують суттєвого втручання.

Найбільші коливання значень інтегральних показників ефективності на підприємстві характерні для соціальної та екологічної складових, отже, ефективність за цими складовими можна вважати нестабільною. Однак аналіз за допомогою діаграми ефективності свідчить, що протягом 2012-2016рр. інтегральні показники ефективності інноваційної діяльності за соціальною й екологічною складовими зазвичай знаходились у зоні “середньої" та "високої” ефективності (крім 2012 р. для соціальної складової). Таким чином, нестабільність ефективності за цими двома складовими не могла суттєво вплинути на узагальнюючий інтегральний показник ефективності інноваційної діяльності підприємства.

На ТОВ "Карпатнафтохім" найбільш нестабільні значення ефективності спостерігались для соціальної та науково-технологічної складових. При цьому тенденції зміни інтегральних показників ефективності інноваційної діяльності для обох складових співпадали в аналізованому періоді, а в 2013-2014рр. для них було характерно розташування у зоні "низької" ефективності. Значення інтегральних показників за іншими складовими ефрективності інноваційної діяльності підприємства характеризувалися достатньо високою стабільністю. Однак зазначена стабільність мала негативний характер для економічної складової, за якою спостерігалися найнижчі значення інтегрального показника ефективності, стабільно розташовані у зоні “низької" ефективності.

На ТОВ "Кеннер-Україна" для інтегральних показників ефективності інноваційної діяльності за всіма складовими в 2012-2016рр. була характерна висока стабільність. Це можна вважати позитивною характеристикою для ресурсної та екологічної складових ефрективності, інтегральні показники за якими в аналізованому періоді стабільно розташовувалися у зоні “високої” ефрективності. Також позитивною є стабільність значень інтегральних показників ефективності за науково-технологічною, маркетинговою, фрінансовою та соціальною складовими, оскільки вони в аналізованому періоді розташовувалися у зоні "середньої" ефективності. Щодо економічної складової ефективності інноваційної діяльності ТОВ “Кеннер-Україна”, то інтегральний показник ефективності за цією складовою протягом п'яти років (2012-2016рр.) стабільно розташовувався у зоні “низької” ефеективності, що мало негативний вплив на узагальнюючий інтегральний показник ефективності інноваційної діяльності підприємства.

З урахуванням здійсненого розподілу аналізованих підприємств за підгрупами можна простежити відмінності у тенденціях зміни узагальнюючого інтегрального показника ефективності їх інноваційної діяльності протягом п'яти років. Для підприємств першої підгрупи характерна плавна, без різких переходів за зонами ефрективності зміна узагальнюючого інтегрального показника ефрективності інноваційної діяльності протягом аналізованого періоду (рис. 1). 
В. Микитюк

Оцінювання ефективності інноваційної ...

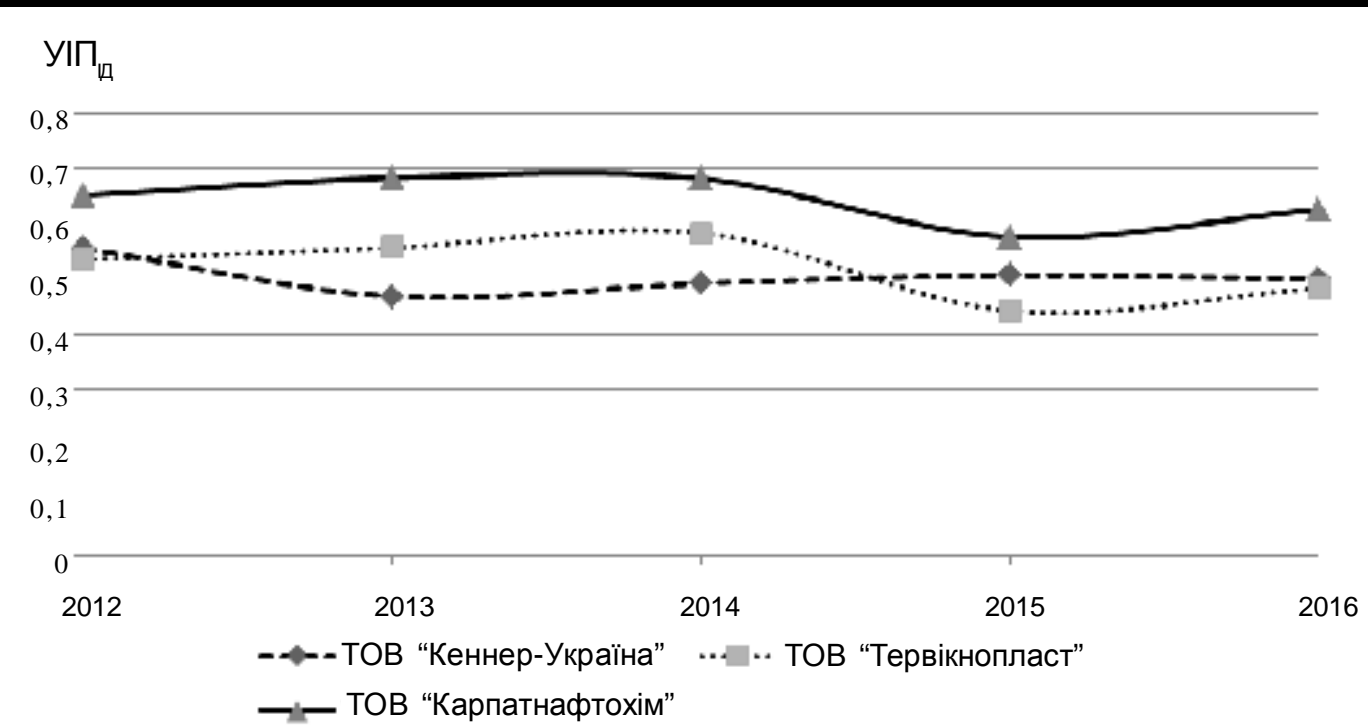

Рис. 1. Динаміка узагальнюючого інтегрального показника ефективності інноваційної діяльності підприємств

Джерело. Складено автором.

Для підприємств другої підгрупи характерні суттєві коливання значень узагальнюючого інтегрального показника ефективності інноваційної діяльності та їх розташування здебільшого у зонах "середньої" та "низької" ефрективності.

На рівні окремого підприємства пропонується використовувати результати аналізу за допомогою пелюсткової діаграми ефрективності та узагальнюючого інтегрального показника ефрективності інноваційної діяльності для обґрунтування заходів щодо ії підвищення.

В процесі розробки управлінських рішень щодо підвищення ефективності інноваційної діяльності підприємства необхідно враховувати: результати оцінки ії ефрективності; ступінь готовності підприємства до забезпечення (фінансового, кадрового, інфрормаційного і т.п.) реалізації ухвалених рішень.

За результатами побудови діаграми ефрективності інноваційної діяльності підприємства та аналізу отриманих результатів до зони “низької" ефективності можуть потрапити декілька ії складових. У такому випадку постає проблема відбору складових, підвищення ефективності за якими є більш вигідним для підприємства з позиції удосконалення його інноваційної діяльності. Відбір складової або декількох складових ефективності інноваційної діяльності підприємства, які потребують першочергового втручання для досягнення максимально можливого їі зростання, рекомендується здійснювати на основі таких критеріїв:

1. Розташування інтегрального показника ефективності інноваційної діяльності підприємства за даною складовою у зоні “низької” ефективності протягом двох-трьох років;

2. Наявність тенденції до зниження інтегрального показника ефективності інноваційної діяльності підприємства за даною складовою;

3. Різке зниження (діапазон зміни перевищує 31\%) значення інтегрального показника ефективності інноваційної діяльності за даною складовою, порівняно зі значенням у попередньому періоді (році). Критична межа діапазону зміни значень інтегральних 
показників ефективності встановлена на рівні 31\%, оскільки коливання ефективності в такому діапазоні може спричинити перехід із “високої" зони ефрективності до “низької".

Крім перелічених критеріїв відбору складових ефективності інноваційної діяльності для удосконалення, на нашу думку, доцільно враховувати вплив зміни ефективності інноваційної діяльності підприємства за певною складовою, на змінуії ефрективності за іншими складовими. Для цього пропонуємо використовувати коефіцієнти парної кореляції між інтегральними показниками ефективності інноваційної діяльності підприємства за всімаїі складовими. Такий підхід дозволить виокремити ті складові ефективності інноваційної діяльності підприємства, поліпшення яких надасть змогу підвищити ефективність інноваційної діяльності якнайбільше.

3 урахуванням запропонованого підходу послідовність відбору та обґрунтування заходів для підвищення ефеективності інноваційної діяльності підприємства має включати етапи, представлені на рис. 2.

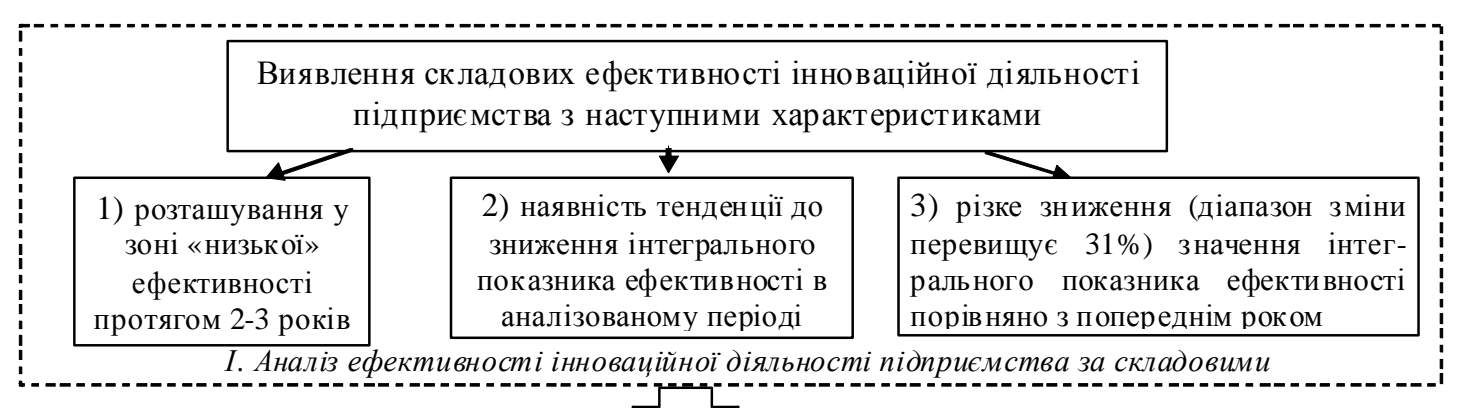

r.

Визначення переліку складових ефективності інноваційної діяльності підприємства, за якими необхідно в першу чергу здійснювати удосконалення

Обгрунтування пріоритетності удосконалення відібраних складових ефективності інноваційної
діяльності підприємства на основі аналізу кореляційних зв’ язків між інтегральними
показниками ефективності за складовими

II. Формування переліку складових ефективності інноваційної діяльності за пріоритетністю

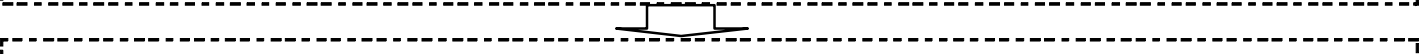
Формування комплексу заходів для підвищення ефективності за кожною складовою
ефективності інноваційної діяльності підприємства III. Визначення комплексу заходів, спрямованих на підвищення ефективності інноваційної діяльності підприсмства для впровадження

\section{Рис. 2. Послідовність етапів відбору заходів щодо підвищення ефективності інноваційної діяльності підприємства за їі складовими для впровадження на підприємстві}

Джерело. Складено автором. 
В. Микитюк

Оцінювання ефективності інноваційної ...

Рекомендована послідовність включає такі етапи:

1) виявлення складових ефективності інноваційної діяльності підприємства, які відповідають трьом зазначеним критеріям;

2) фрормування переліку складових ефективності інноваційної діяльності з урахуванням існуючих між ними кореляційних зв'язків, що дозволяє визначити пріоритетність відібраних складових для вдосконалення;

3) визначення конкретних заходів для підвищення ефективності інноваційної діяльності підприємства на основі результатів її аналізу з урахуванням пріоритетності відібраних складових для даного підприємства.

Формування комплексу заходів, які впливають на підвищення ефективності інноваційної діяльності за її складовими, здійснювалося на основі дослідження праць авторів [1-11] та запропонованої системи показників ефективності інноваційної діяльності підприємства за складовими. Узагальнені та систематизовані за складовими ефективності інноваційної діяльності підприємства заходи, спрямовані на її підвищення, наведено в табл. 2.

Комплекс заходів для підвищення ефективності інноваційної діяльності

Таблиия 2 підприємства за її складовими

\begin{tabular}{|c|c|}
\hline $\begin{array}{c}\text { Складова } \\
\text { ефективності } \\
\text { ІДП }\end{array}$ & Заходи для підвищення ефективності інноваційної діяльності \\
\hline Економічна & $\begin{array}{l}\text { 1. Придбання, розроблення нематеріальних активів для підприємства. } \\
\text { 2. Впровадження інноваційних розробок щодо автоматизації, механізації } \\
\text { виробничого процесу та допоміжних робіт. } \\
\text { 3. Комп'ютеризація процесу обробки інформації для аналізу, обліку та } \\
\text { здій снення необхідних розрахунків. } \\
\text { 4. Забезпечення процесу виробництва контрольно-вимірювальними } \\
\text { приладами високого науково-технологічного рівня. } \\
\text { 5. Прискорення процесу впровадження результатів науково-технологічних } \\
\text { досліджень. } \\
\text { 6. Активізація патентно-ліцензійної діяльності на підприємстві. } \\
\text { 7. Збільшення обсягів реалізації за рахунок випуску інноваційної продукції } \\
\text { (робіт, послуг). } \\
\text { 8. Заміна застарілого обладнання, що застосовується на виробництві } \\
\text { інноваційної продукції. }\end{array}$ \\
\hline Маркетингова & $\begin{array}{l}\text { 1. Здійснення маркетингових досліджень щодо попиту на інноваційну } \\
\text { продукцію (роботи, послуги), запитів споживачів. } \\
\text { 2. Зростання обсягів інновацій ної продукції (робіт, послуг), реалізованих } \\
\text { за межі країни та на внутрішньому ринку. } \\
\text { 3. Забезпечення випуску інноваційної продукції (робіт, послуг), що заново } \\
\text { впроваджені на підприємстві. } \\
\text { 4. Розширення асортименту інноваційної продукції (робіт, послуг) } \\
\text { підприємства. }\end{array}$ \\
\hline $\begin{array}{c}\text { Науково- } \\
\text { технологічна }\end{array}$ & $\begin{array}{l}\text { 1. Здійснення наукових досліджень власними силами підприємства. } \\
\text { 2. Зростання кількості впровадженихвласних інноваційних розробок. } \\
\text { 3. Активізація роботи з придбання інноваційних розробок } \\
\text { впровадження їх у діяльність підприємства. } \\
\text { 4. Збільшення кількості впроваджених нових технологічних процесів. }\end{array}$ \\
\hline
\end{tabular}


Продовження таблиці 2

\begin{tabular}{|c|c|}
\hline Фінансова & $\begin{array}{l}\text { 1. Збільшення обсягів фрінансування інноваційної діяльності за рахунок } \\
\text { власних, залучених та позико вих коштів. } \\
\text { 2. Оптимізація потенційних джерел інвестування інноваційної діяльності } \\
\text { (прибутковість залучених та позикових коштів повинна перевищувати } \\
\text { прибутковість власних коштів). } \\
\text { 3. Підвищення рівня використання нематеріальних активів і забезпечення } \\
\text { їх прибутковості. } \\
\text { 4. Раціональна організація матеріально-технічного забезпечення } \\
\text { інноваційної діяльності. } \\
\text { 5. Використання фракторингу для фрінансування інновацій на підприємстві. }\end{array}$ \\
\hline Соціальна & $\begin{array}{l}\text { 1. Збільшення кількості працівників, охоплених автоматизацією, } \\
\text { механізацією, що поліпшують умови їхпраці. } \\
\text { 2. Створення безпечних умов праці за рахунок впровадження нових } \\
\text { технолопчних процесів та додаткового оснащення робочих місць } \\
\text { засобами захисту. } \\
\text { 3. Створення нових робочих місць для випуску інноваційної продукції } \\
\text { (робіт, послуг). } \\
\text { 4. Забезпечення ефективного використання робочого часу та виробничих } \\
\text { потужностей підприємства для виробництва інноваційної продукції. } \\
\text { 5. Забезпечення процесу виробництва інноваційної продукції (робіт, } \\
\text { послуг) кадрами високої кваліфрікації. } \\
\text { 6. Систематичне підвищення кваліфрікації працівників підприємства, } \\
\text { зайнятих на виробництві інноваційної продукції (робіт, послуг). }\end{array}$ \\
\hline Ресурсна & $\begin{array}{l}\text { 1. Впровадження ресурсозберігаючих технологічних процесів. } \\
\text { 2. Розробка та впровадження інноваційних технологічних процесів. } \\
\text { 3. Збільшення матеріаловіддачі інноваційної продукції за рахунок } \\
\text { застосування матеріалозберігаючих та енергозберігаючих технологій. } \\
\text { 4. Використання у виробництві вторинних матеріальних та енергетичних } \\
\text { ресурсів (відходи, попутна та побічна продукція). } \\
\text { 5. Впровадження маловідходних та безвідходнихвиробництв. } \\
\text { 6. Зниження витрат усіх видів ресурсів, пов'язаних з виробництвом } \\
\text { інноваційної продукції. } \\
\text { 7. Зниження запасів матеріально-технічних ресурсів та раціональна } \\
\text { організація купівлі, збереження і використання ресурсів. }\end{array}$ \\
\hline Екологічна & $\begin{array}{l}\text { 1. Удосконалення технології виробництва інноваційної продукції з метою } \\
\text { зниження екологічно шкідливих викидів у атмосферу, землю та воду. } \\
\text { 2. Здійснення науково-дослідних робіт з питань обліку, нейтралізації та } \\
\text { використання у виробництві екологічно шкідливих відходів. } \\
\text { 3. Організація виробничих дільниць з доведення відходів, які потенційно } \\
\text { можливо використовувати у виробництві, до відповідного стану. } \\
\text { 4. Здійснення заходів щодо обліку шкідливих та небезпечних відходів ви- } \\
\text { робництва, організації їх збору, збереження, транспортування та } \\
\text { ліквідації. }\end{array}$ \\
\hline
\end{tabular}

Джерело. Складено автором самостійно в результаті аналізу [1-11]. 
В. Микитюк

Оцінювання ефективності інноваційної ...

Апробацію запропонованої послідовності відбору заходів, спрямованих на підвищення ефрективності інноваційної діяльності підприємства, було виконано для підприємств кожної з виділених трьох груп.

Серед підприємств першої групи з цією метою було обрано ТОВ "Карпатнафртохім", оскільки серед підприємств-представників першої групи воно єдине увійшло до другої підгрупи. Для цього підприємства характерна наявність декількох складових ефективності інноваційної діяльності, розташованих у зоні “низької” ефрективності.

На першому етапі було проаналізовано отримані значення інтегральних показників ефрективності інноваційної діяльності ТОВ “Карпатнафртохім" у 2016 р. за допомогою діаграми ефрективності (рис. 3) для визначення складових ефективності, що відповідають першому критерію відбору.

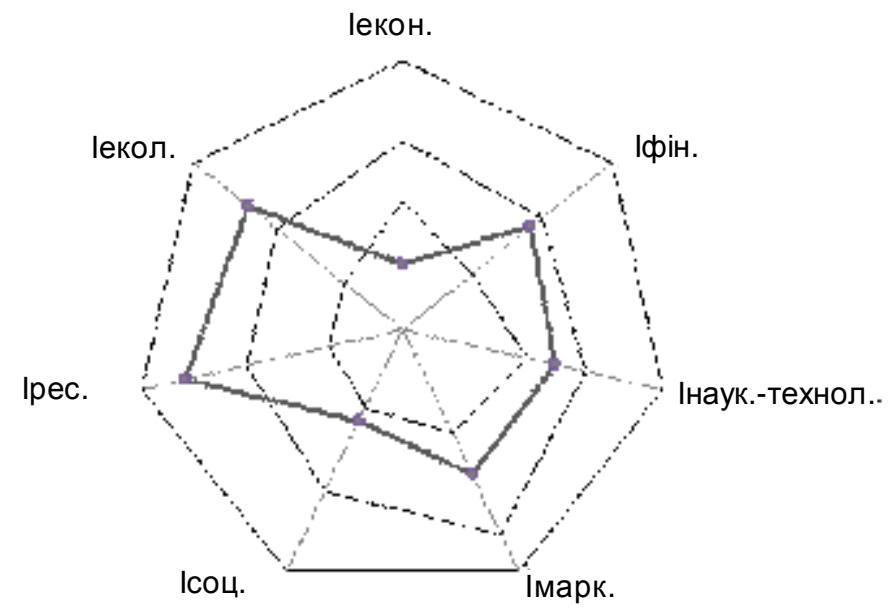

Рис. 3. Діаграма ефективності інноваційної діяльності ТОВ “Карпатнафтохім"

Джерело. Складено автором.

Побудована діаграма ефективності інноваційної діяльності дозволила визначити, що в 2016 р. на підприємстві в зоні “низької” ефективності опинилася економічна складова ефрективності інноваційної діяльності, в зоні “середньоі” ефективності - фінансова, науковотехнологічна, маркетингова і соціальна складові, у зоні “високої” ефективності - ресурсна та екологічні складові.

Перевірка на наявність складових з тенденцією щодо зниження інтегрального показника ефективності інноваційної діяльності (другий критерій відбору) в аналізованому періоді здійснювалася за допомогою рис. 4.

Аналіз динаміки інтегральних показників ефективності інноваційної діяльності підприємства в 2012-2016 рр. свідчить, що для маркетингової та соціальної складових в зазначеному періоді була характерна негативна тенденція. Виключення становили значення інтегральних показників ефективності ІДП за маркетинговою складовою в 2014 p. (зростання на 8\%) і за соціальною складовою в 2015 р. (збільшення в 2,7 рази). 
Слід зазначити, що на ТОВ “Карпатнастохім" в 2016 р. не спостерігалося різкого зниження значень інтегрального показника ефективності інноваційної діяльності за жодною складовою (третій критерій відбору). Максимальний діапазон зміни інтегрального показника ефективності інноваційної діяльності підприємства становив 17,6\% для ії екологічної складової.

Таким чином, на ТОВ “Карпатнафртохім” до переліку складових ефрективності інноваційної діяльності, для яких необхідно здійснювати удосконалення, в першу чергу, увійшли: економічна, маркетингова та соціальна складові.

Інтегральні показники

ефеективності

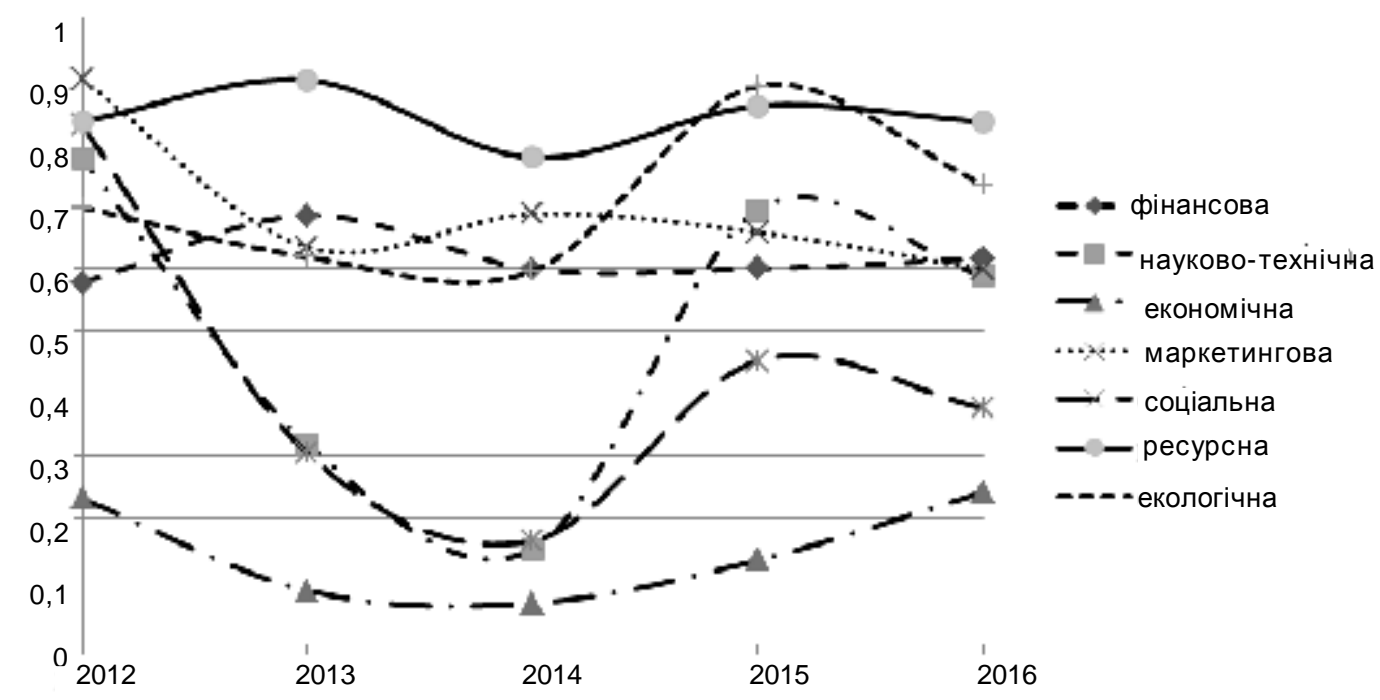

Рис. 4. Динаміка інтегральних показників ефективності інноваційної діяльності за її складовими на ТОВ “Карпатнафтоххім"

Джерело. Складено автором.

На другому етапі необхідно визначити пріоритетність відібраних складових ефрективності інноваційної діяльності підприємства для ії підвищення на основі аналізу кореляційних зв'язків (табл. 3).

Результати кореляційного аналізу свідчать, що підвищення ефективності інноваційної діяльності за економічною складовою спричинить її зниження за фінансовою складовою на 44,2\%. Аналогічна ситуація спостерігається щодо підвищення ефективності інноваційної діяльності за маркетинговою та соціальною складовою. Тому, на нашу думку, доцільно здійснити удосконалення науково-технологічної складової ефективності інноваційної діяльності ТОВ "Карпатнафтохім", яке здатне забезпечити підвищення ефективності інноваційної діяльності за економічною складовою на 80\%, за соціальною складовою на 79,6\% і за маркетинговою складовою - на 43,9\%. 
Кореляція інтегральних показників ефективності інноваційної діяльності за її складовими для ТОВ “Карпатнафтохім”

\begin{tabular}{|c|c|c|c|c|c|c|c|}
\hline $\begin{array}{c}\text { Інтегральні } \\
\text { показники } \\
\text { ефрективності ІДП за } \\
\text { Складовими }\end{array}$ & $\begin{array}{l}\text { Фінан- } \\
\text { совою }\end{array}$ & $\begin{array}{l}\text { Науково- } \\
\text { техноло- } \\
\text { гічною }\end{array}$ & $\begin{array}{l}\text { Еконо- } \\
\text { мічною }\end{array}$ & $\begin{array}{l}\text { Марке- } \\
\text { тин } \\
\text { говою }\end{array}$ & $\begin{array}{l}\text { Соціаль- } \\
\text { ною }\end{array}$ & $\begin{array}{l}\text { Pecypc- } \\
\text { Hою }\end{array}$ & $\begin{array}{l}\text { Еколо- } \\
\text { гічною }\end{array}$ \\
\hline Фінансовою & & & $-0,442$ & $-0,584$ & $-0,488$ & 0,694 & $-0,353$ \\
\hline $\begin{array}{c}\text { Науково- } \\
\text { технологічною }\end{array}$ & & & & 0,439 & 0,796 & 0,269 & 0,733 \\
\hline Економічною & & & & & 0,710 & 0,006 & 0,362 \\
\hline Маркетинговою & & & & & & $-0,207$ & $-0,092$ \\
\hline Соціальною & & & & & & 0,173 & 0,338 \\
\hline Ресурсною & & & & & & & 0,240 \\
\hline Екологічною & & & & & & & $I 5$ \\
\hline
\end{tabular}

Примітка:

$\square$ - позитивний вплив підвищення ефективності за даною складовою на зміну ефективності за іншими складовими

Джерело. Складено автором.

На третьому етапі було визначено комплекс заходів, які підлягають першочерговому впровадженню на підприємстві для забезпечення підвищення ефективності його інноваційної діяльності. Для ТОВ "Карпатнафтохім" до цього комплексу увійшли заходи для підвищення ефеективності інноваційної діяльності за науково-технологічною складовою: 1) здійснення наукових досліджень власними силами підприємства; 2) зростання кількості впроваджених власних інноваційних розробок; 3) активізація роботи з придбання інноваційних розробок та впровадження їх у діяльність підприємства; 4) забезпечення зростання кількості впроваджених нових технологічних процесів.

Оскільки за результатами аналізу на ТОВ "Карпатнафртохім" виявлено відсутність витрат на наукові дослідження та розробки протягом 2012-2016 років, то впровадження рекомендованих заходів має покращити ситуацію в науково-технологічній складовій інноваційної діяльності підприємства і сприяти підвищенню ії̈ ефективності в 2017 р. і подальших роках.

Висновки та перспективи подальших досліджень. Застосування запропонованих рекомендацій щодо підвищення ефективності інноваційної діяльності на основі результатів ії оцінки в управлінні вітчизняними промисловими підприємствами дозволить їм функціонувати та розвиватись, підвищуючи свою конкурентоспроможність за рахунок ефективного здійснення інноваційної діяльності.

\section{Список використаних джерел}

1. Антонюк Л. Л. Інновації: теорія, механізм розробки та комерціалізації : монографрія / Л. Л. Антонюк, А. М. Поручник, В. С. Савчук. -К. : КНЕУ, 2003. $394 \mathrm{c.}$

2. Бондарчук Р. Стратегія рефрормування науково-технічної сфери оборонно- 
промислового комплексу України / Р. Бондарчук // Економіка України. - 2003. № 8. - C. 27-32.

3. Бородіна О. Людський капітал як основне джерело економічного зростання / О. Бородіна // Економіка Украӥни. - 2003. - № 7. - С. 48-53.

4. Гриньов А. В. Інноваційний розвиток промислових підприємств: концепиія, методологія, стратегічне управління / А. В. Гриньов. - Харків : ВД “НЖЕК”, 2003. -308 c.

5. Економіка України: стратегія і політика довгострокового розвитку : моногр. / В. М. Геєць, В. П. Александрова, Т. І. Артьомова [та ін.] ; НАН України. Ін-т екон. прогнозування. - К. : Фенікс, 2003. - 1006 c.

6. Зведений прогноз науково-технологічного та інноваційного розвитку України на найближчі 5 років та наступне десятиліття /В. М. Геєць, В. П. Александрова, М. І. Скрипниченко [та ін.]; Центр досліджень наук.-техн. потенціалу та історії науки ім. Г. М. Доброва НАН України. -К. : Фенікс, 2007. - 152 c.

7. Інноваційний механізм управління суб'єктами господарювання :моногр. /П. П. Микитюк, Ж. Л. Крисько, В. І. Гринчуцький [та ін.] ; за заг. ред. П. П. Микитюка. Тернопіль : Економічна думка, 2014. -450 с.

8. Інновації: проблеми науки і практики : моногр. - Харків : ВД “НЖЕК”, 2006. $336 \mathrm{c.}$.

9. Мешко Н. П. Механізм управління інвестиційно-інноваційним потенціалом: макрорівень : моногр. / Н. П. Мешко. -Дніпропетровськ : Наука і освіта, 2004. 272 c.

10. Проблеми управління інноваційним розвитком підприємств у транзитивній економіці : моногр.; за заг. ред. С. М. Ілляшенка. - Суми : ВТД 'Університетська книга", 2005. -582 c.

11. Стратегічне управління організаційними перетвореннями на промислових підприємствах / В. С. Пономаренко, А. М. Золотарьов, О. М. Ястремська [та ін.]; за заг. ред. В. С. Пономаренка, О. М. Ястремської. -Харків :ХНЕУ, 2005. $452 \mathrm{c}$.

\section{References}

1. Antoniuk L. L. Innovatsii: teoriia, mekhanizm rozrobky ta komertsializatsii: monohrafiia [Innovations: theory, mechanism of development and commercialization: monograph]. Kyiv: KNEU, 2003, 394 p. [in Ukrainian].

2. Bondarchuk R. Stratehiia reformuvannia naukovo-tekhnichnoi sfery oboronnopromyslovoho kompleksu Ukrainy [Strategy of reforming the scientific and technical sphere of the defense industrial complex of Ukraine]. Ekonomika Ukrainy-Economy of Ukraine, 2003, No. 8, pp. 27-32 [in Ukrainian].

3. Borodina O. Liudskyi kapital yak osnovne dzherelo ekonomichnoho zrostannia [Human capital as the main source of economic growth]. Ekonomika Ukrainy - Economy of Ukraine, 2003, No. 8, pp. 48-53 [in Ukrainian].

4. Hrynov A. V. Innovatsiinyi rozvytok promyslovykh pidpryiemstv: kontseptsiia, metodolohiia, stratehichne upravlinnia [Innovative development of industrial enterprises: 
concept, methodology, strategic management]. Kharkiv: VD "INZhEK", 2003, 308 p. [in Ukrainian].

5. Heiets V. M., Aleksandrova V. P., Artomova T. I. ta in. Ekonomika Ukrainy: stratehiia i polityka dovhostrokovoho rozvytku: monohrafiia [Economy of Ukraine: strategy and policy of long-term development: monograph]. Kyiv: Feniks, 2003, 1006 p. [in Ukrainian].

6. Heiets V. M., Aleksandrova V. P., Skrypnychenko M. I. ta in. Zvedenyi prohnoz naukovotekhnolohichnoho ta innovatsiinoho rozvytku Ukrainy na naiblyzhchi 5 rokiv ta nastupne desiatylittia [Consolidated forecast of Ukraine's scientific-technological and innovation development for the upcoming 5 years and decade]. Kyiv: Feniks, 2007, 152 p. [in Ukrainian].

7. Mykytiuk P. P., Krysko Zh. L., Hrynchutskyi V. I. ta in. Innovatsiinyi mekhanizm upravlinnia subiektamy hospodariuvannia: monohrafiia [Innovative mechanism for managing entities: monograph]. Ternopil: Ekonomichna dumka, 2014, 450 p. [in Ukrainian].

8. Innovatsii: problemy nauky i praktyky: monohrafiia [Innovations: challenges for research and practice: monograph]. Kharkiv: VD “INZhEK", 2006, 336 p. [in Ukrainian].

9. Meshko N. P. Mekhanizm upravlinnia investytsiino-innovatsiinym potentsialom: makroriven: monohrafiia [Mechanism for managing investment-innovation potential: macro level: monograph]. Dnipropetrovsk: Nauka i osvita, 2004, 272 p. [in Ukrainian].

10. Problemy upravlinnia innovatsiinym rozvytkom pidpryiemstv u tranzytyvnii ekonomitsi: monohrafiia [Issues of management of innovative development of enterprises in a transitive economy: monograph]. Sumy: VTD “Universytetska knyha”, 2005, 582 p. [in Ukrainian].

11. Ponomarenko V. S., Zolotarov A. M., Yastremska O. M. ta in. Stratehichne upravlinnia orhanizatsiinymy peretvorenniamy na promyslovykh pidpryiemstvakh [Strategic management of organizational transformations at industrial enterprises]. Kharkiv: KhNEU, 2005, 452 p. [in Ukrainian].

Редакція отримала матеріал 25 вересня 2017 р. 